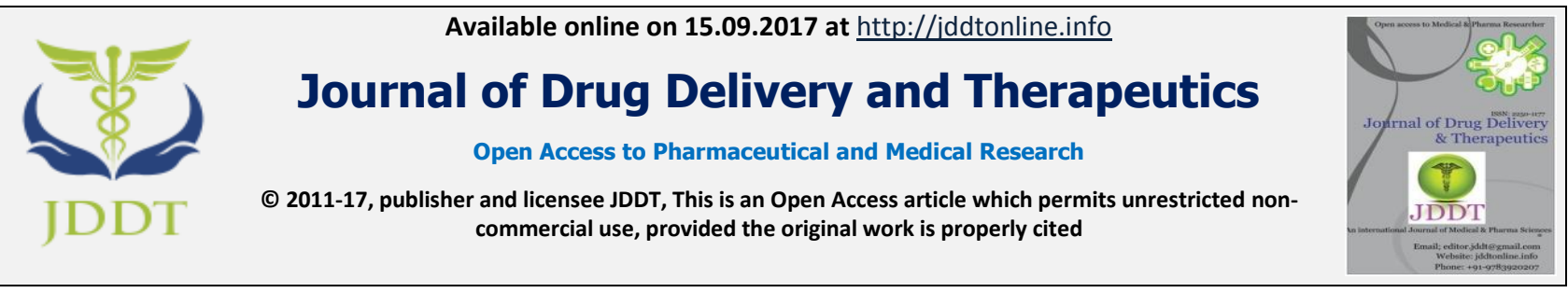

Open $\odot$ Access

Research Article

\title{
PHARMACEUTICAL STANDARDIZATION OF BALADI MANDURAM
}

\author{
${ }^{1}$ *Dr. Kishore Kumar Hanumanthu, ${ }^{2}$ Dr. Sridurga CH, M.D. (Ayu), Ph.D \\ ${ }^{1}$ PG Scholar final year, Department of Rasa Shastra and Bhaishajya Kalpana, S.V. Ayurvedic College, Tirupati-517501, Andhra Pradesh, \\ India \\ ${ }^{2}$ Associate Professor and HOD, Department of Rasa Shastra and Bhaishajya Kalpana, S.V. Ayurvedic College, Tirupati-517501, Andhra \\ Pradesh, India
}

\section{ABSTRACT}

Objective: Baladi Manduram $(B M)$ is one of the most important and potent herbo-mineral formulation described in Ayurvedic classics viz., Rasa Kamadhenu and Rasayoga sagara specified for the management of the disease Amlapitta. BM contains Mandura Bhasma, Balamula, Satavarimula, Erandamula, Yava, Pippali, Jiraka, Twak, Ela, Patra, Nagakesara and Guda. Till now no research work has been carried out to standardize the preparation of $B M$. The main objective of the present study is to standardize the method of preparation of $B M$ according to the conventional method mentioned in classical literatures.

Methods: Shodhana, Bhavana, Marana, Churna nirmana and Paka are the main pharmaceutical procedures involved in the preparation of BM. Mandura was subjected to Shodhana by Nirvapa in Gomutra Triphala Kashaya for 7 times. Shodhita Mandura thus obtained was triturated with Kumari Swarasa and subjected to Gaja puta for 7 times. Mandura Bhasma thus otained was added to the guda paka along with the fine powders of herbal ingredients. Then the homogenous mixture of $B M$ was made in the form of capsules of 500mg.

Results: $1380 \mathrm{~g}$ of BM was prepared from 1264g of Mandura Bhasma, 100g each of Balamula, Satavarimula, Erandamula and Yava, $50 \mathrm{~g}$ each of Pippali and Jiraka and $8 \mathrm{~g}$ each of Twak, Ela, Patra and Nagakesara.

Conclusion: All these procedures can be considered ideal in the standardization of the preparation of Baladi Manduram.

Keywords: Baladi Manduram, Shodhana, Bhavana, Marana, Churna nirmana, Paka, Standardization.

Article Info: Received 10 July, 2017; Review Completed 28 Aug, 2017; Accepted 29 Aug, 2017; Available online 15 Sep, 2017

\section{Cite this article as:}

Hanumanthu KK, Sridurga Ch, Pharmaceutical standardization of baladi manduram, Journal of Drug Delivery and Therapeutics. 2017; 7(5):61-67

DOI: http://dx.doi.org/10.22270/jddt.v7i5.1488

\section{*Address for Correspondence}

Dr. Kishore Kumar Hanumanthu, PG Scholar final year, Department of Rasa Shastra and Bhaishajya Kalpana, S.V. Ayurvedic College, Tirupati-517501, Andhra Pradesh, India. E-mail: kishorekumarbams@gmail.com

\section{INTRODUCTION}

Rasa Shastra and Bhaishajya Kalpana are considered as the pharmaceutical branch of Ayurveda. Most of the preparations of Rasa Shastra are Herbo-mineral-metallic in nature, as they contain minerals and metals as an integral part of their formulations along with the specified herbs.
The use of metals and minerals were found since Vedic period. Their use in therapeutics was limited probably due to their non-conversion into suitable pharmaceutical form viz., Bhasma. But after the development of Rasa Shastra with the well-defined pharmaceutical processes like Shodhana, Jarana, Marana, Bhavana etc. their use in therapeutics occupied highest place and is called as Rasa chikitsa. 
Various therapeutic effects of Mandura have been elucidated in different texts of Rasa Shastra. Baladi Manduram is a unique formulation mentioned in classics like Rasa Kamadhenu Amlapitta rogadikaral and Rasa yoga sagara- II Pakaradi Rasa ${ }^{2}$. It contains Mandura Bhasma as the chief ingredient along with the herbal drugs like Balamula, Satavarimula, Erandamula, Yava, Pippali, Jiraka, Twak, Ela, Patra, Nagakesara and Guda.

Pharmaceutical processes involved in the preparation of Baladi Manduram are Shodhana, Bhavana and Marana of Mandura, Churna nirmana of herbal ingredients and preparation of Baladi Manduram. Hence an effort has been made in the present study to standardize the method of preparation of Baladi Manduram.

\section{MATERIALS AND METHODS}

\section{Procurement of Raw material}

Mandura and Triphala were obtained from local market of Chennai, Tamil Nadu. Balamula, Satavarimula, Erandamula, Yava, Pippali, Jiraka, Twak, Ela, Patra, Nagakesara, Guda and Kumari were obtained from TTD's Sri Srinivasa Ayurveda Pharmacy, Tirupati. Gomutra was collected from the Goshala of ISCKON temple, Tirupati.

\section{Methods}

Entire preparation of Baladi Manduram was carried out in TTD's Sri Srinivasa Ayurveda Pharmacy and Department of Rasa Shastra and Bhaishajya Kalpana, S.V.Ayurvedic College, Tirupati.

Total pharmaceutical study was carried out in the following stages

\section{Stage - I}

- Triphala Kwatha nirmana with gomutra.

- Mandura Shodhana.

Stage - II

- Kumari Swarasa nirmana.

- Mandura Marana.

Stage - III

- Preparation of Balamula Churna.

- Preparation of Satavarimula Churna.

- Preparation of Yava Churna.

- Preparation of Erandamula Churna.

- Preparation of Pippali Churna.

- Preparation of Jiraka Churna.

- $\quad$ Prepatation of Twak Churna.

- Preparation of Ela Churna.

- Preparation of Patra Churna.

- Preparation of Nagakesara Churna.
Stage - IV

- $\quad$ Paka of all Herbal drugs along with Guda and double quantity of Mandura Bhasma.

\section{Stage - V}

- Semi solid paste of drug dried in sun light and made into powder (Baladi Manduram)

- Preparation of capsules of Baladi Manduram.

Procedure

I. Gomutra Triphala Kashaya Nirmana: Gomutra was taken in a stainless steel vessel and coarse powder of Triphala was added to it. It was subjected to moderate fire till the liquid part was reduced to $1 / 4^{\text {th }}$ quantity. Then it was filtered through a clean cloth and Gomutra Triphala Kashaya was collected.

Observations: Brown coloured Gomutra Triphala Kashaya emitting peculiar smell of Gomutra was obtained.

II. Mandura Shodhana: Mandura pieces were heated to red hot in an iron pan and quenched in sufficient quantity of Gomutra Triphala Kashaya. The same procedure was repeated for six more times by changing the Kashaya each time.

Observations: During every nirvapa, time taken for the Mandura to become red hot was gradually decreased. Hissing sound was produced during quenching of red hot Mandura in Gomutra Triphala Kashaya. Brownish grey coloured coarse powder of Shodhitha Mandura was obtained after seven nirvapa. Boiling of Gomutra Triphala Kashaya was observed while quenching red hot Mandura in the Kashaya.

III. Mandura Marana: Shuddha Mandura was taken and pounded in a khalwa yantra to fine powder. It was subjected to Bhavana with sufficient quantity of Kumari Swarasa till it attains semisolid consistency. Chakrikas of uniform size and shape were prepared and dried. They were placed in a Sharava and sandhibhandhana was done using Multani mitti. Sharava samputa was dried and subjected to Gajaputa. This procedure was repeated for six more times. The temperature was recorded by pyrometer and reading was taken for every thirty minute.

Observations: Maximum temperature attained in Gaja puta was $1003^{\circ} \mathrm{C}$ after 210 minutes. Consistency of the pellets was very soft after puta. While giving first Bhavana, it took seven hours to attain subhavita lakshanas. On subsequent putas however the grinding became easier due its powdery nature and Bhavana completed within three hours. Gradual change in the colour of the Mandura was noticed after every puta. Mandura turned from Blackish grey to greyish brown, dark brown, and then to brownish red by the end of $6^{\text {th }}$ puta. Red coloured Mandura Bhasma was obtained after $7^{\text {th }}$ puta. Slakshnatwa was obtained after $3^{\text {rd }}$ puta, 
Rekhapurnatwa after $6^{\text {th }}$ puta and Varitarwatva after $7^{\text {th }}$ puta.

IV. Churna Nirmana: Raw materials of Balamula, Satavarimula, Erandamula, Yava, Pippali, Jiraka, Twak, Ela, Patra and Nagakesara were collected and cleaned to remove external impurities if any and completely dried. They were pounded in a khalwa yantra separately and sieved through a clean cloth to obtain fine powder.

Observations: Very fine churna of individual drugs have been obtained.

V. Paka of all churnas along with Guda and Mandura Bhasma: 2 pala of Guda was taken in a stainless steel vessel and sufficient quantity of water was added to it and heated on mandagni. After 20 minutes of heating, Paka lakshanas appeared. Fine powders of herbal drugs (2 Pala of Balamula, Satavarimula, Erandamula, Yava; 1 pala of Pippali, Jiraka; 1 masha of Twak, Ela, Patra, Nagakesara) and double the quantity of Mandura Bhasma was added one by one to it and mixed properly. The mixture was heated on Mandagni for 15 minutes with continuous stirring to avoid charring of powders. After self-cooling, it was taken out from the stove carefully and dried under sunlight in a tray. (Note: 1 pala $=50 \mathrm{~g}$, 1 masha $=8 \mathrm{~g}$ )

Observations: Red coloured semisolid paste of Baladi Manduram was obtained after paka.

VI. Preparation of capsules of Baladi Manduram: Homogenous mixture of Baladi Manduram was filled in capsules of $500 \mathrm{mg}$. Capsule filling was done with capsule filling machine.
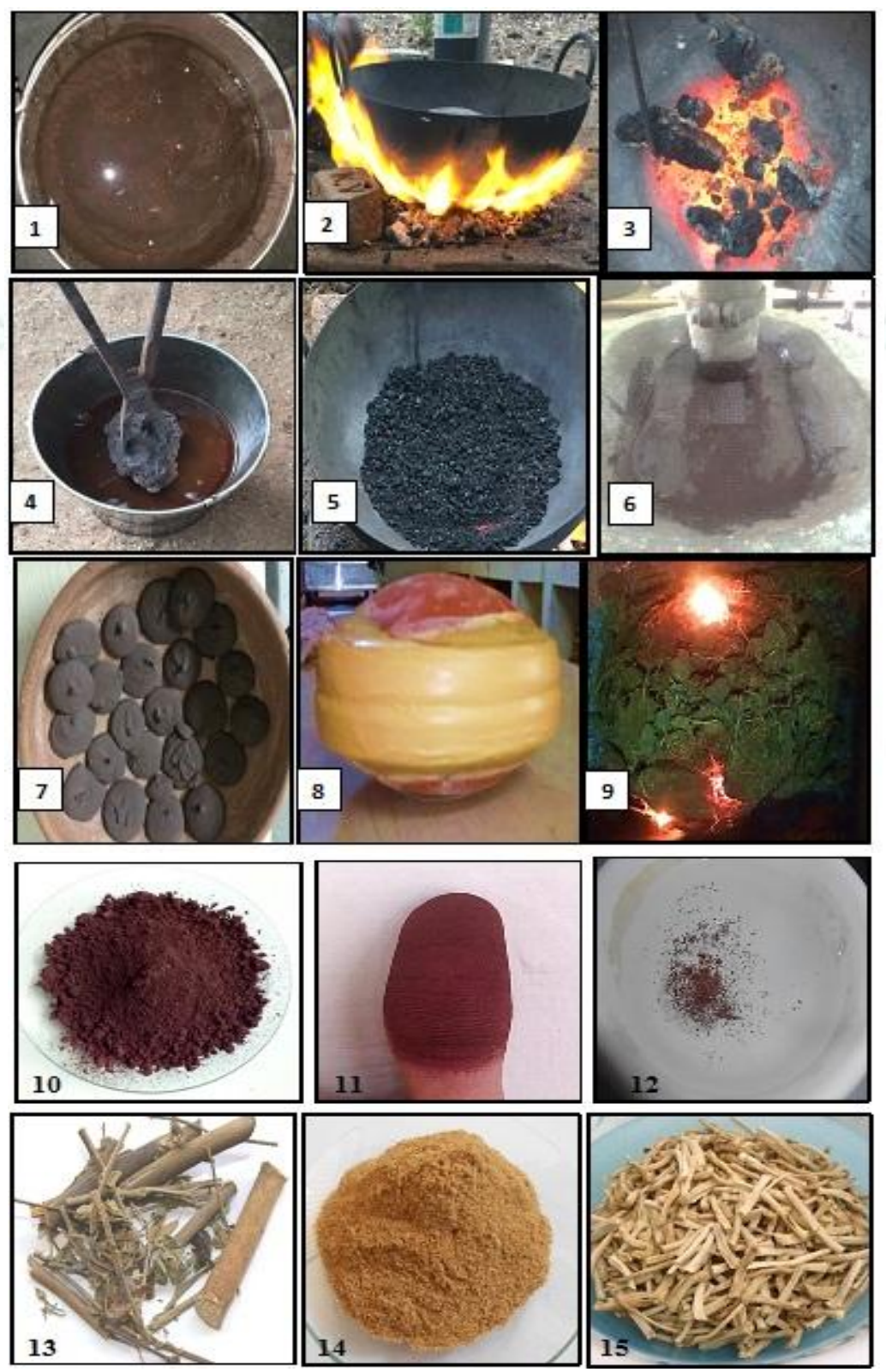

Figure: 1A: 1- Triphala Gomutra Kashaya; 2- Heating of Mandura; 3- Red hot Mandura; 4- Nirvapa in Gomutra Triphala Kashaya; 5- Shuddha Mandura after seven Nirvapa; 6- Bhavana of Mandura with Kumari Swarasa; 7- Chakrikas after Bhavana; 8Sharava Samputa; 9- Gaja Puta; 10- Mandura Bhasma; 11- Rekhapurnatwa; 12- Varitaratwa; 13- Bala moola;14- Bala moola Churna; 15-Shatavari; 

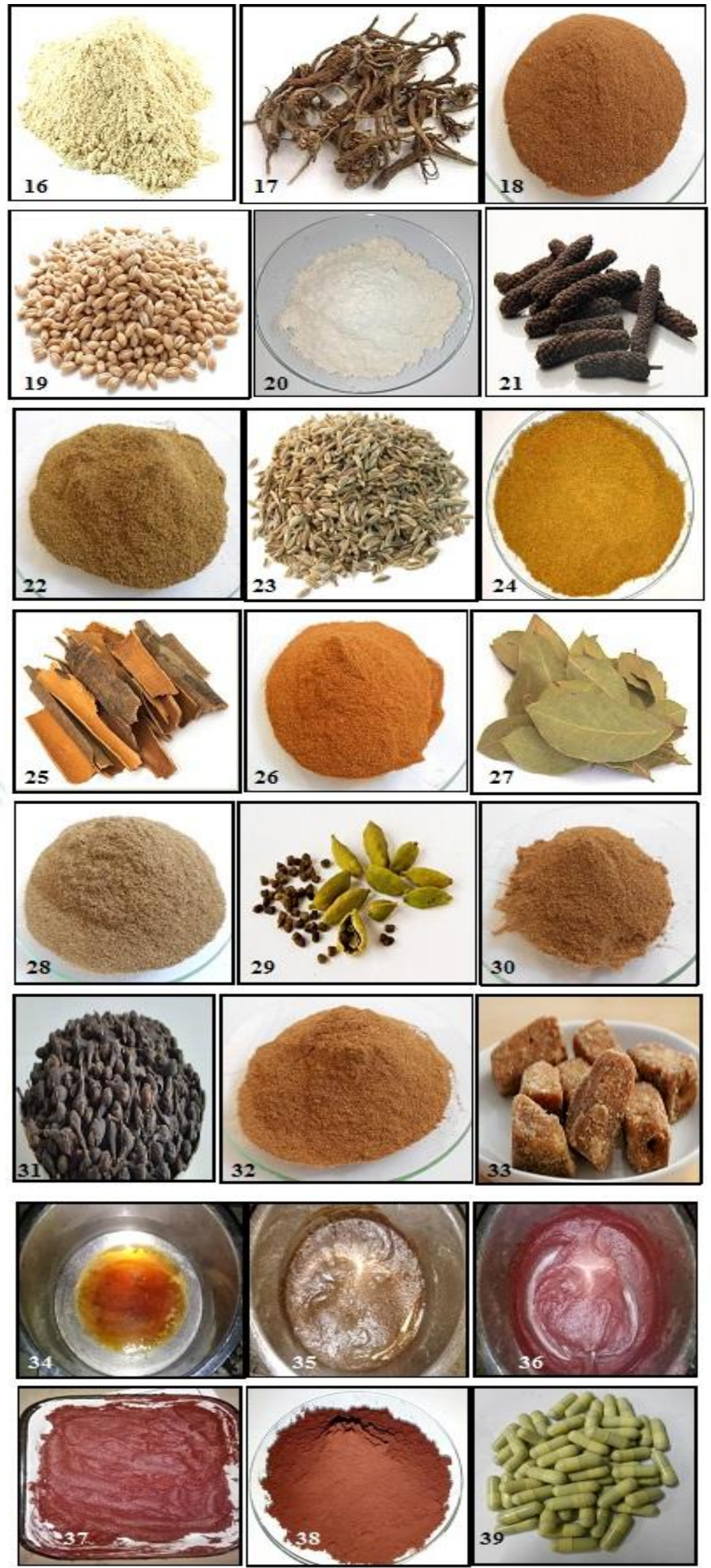

Figure: 1B: 16- Shatavari Churna; 17- Eranda moola;18-Eranda moola Churna; 19- Yava; 20- Yava Churna; 21- Pippali 22Pippali Churna; 23- Jeeraka; 24- Jeeraka Churna; 25- Twak; 26- Twak Churna; 27- Patra; 28- Patra Churna; 29- Ela; 30- Ela Churna; 31- Nagakesara; 32- Nagakesara Churna; 33- Guda; 34- Boiling of Guda to obtain paka; 35- Fine powders of herbal drugs added to the paka; 36- Mandura Bhasma added to the mixture; 37- Drying of whole mixture; 38- Homogenous Mixture (Baladi Manduram); 39- Capsules of Baladi Manduram. 


\section{RESULTS}

Table 1: Showing the result of preparation of Gomutra Triphala Kashaya:

\begin{tabular}{|c|c|c|}
\hline Weight of Triphala & Weight of Gomutra & Weight of Gomutra Triphala Kashaya \\
\hline Haritaki- $2 \mathrm{kgs}$ & $42 \mathrm{~L}$ & $10.5 \mathrm{~L}$ \\
Vibhitaki- $2 \mathrm{kgs}$ & & \\
Amlaki $-2 \mathrm{kgs}$ & & \\
\hline
\end{tabular}

Table 2: Showing the result of Mandura Shodhana:

\begin{tabular}{|c|c|c|}
\hline Initial Weight of Mandura & Final Weight of Mandura & Loss in Weight \\
\hline $2000 \mathrm{~g}$ & $1800 \mathrm{~g}$ & $200 \mathrm{~g}$ \\
\hline
\end{tabular}

Table 3: Showing the result of Mandura Marana:

\begin{tabular}{|c|c|c|}
\hline Initial Weight before Marana & Final Weight after Marana & Loss in Weight \\
\hline $1800 \mathrm{~g}$ & $1575 \mathrm{~g}$ & $225 \mathrm{~g}$ \\
\hline
\end{tabular}

Table 4: Showing the Temperature pattern of Gajaputa

\begin{tabular}{|c|c|}
\hline Time in minutes & Temparature (degree celsius) \\
\hline 0 & 24 \\
\hline 30 & 125 \\
\hline 60 & 300 \\
\hline 90 & +1 \\
\hline 120 & 775 \\
\hline 150 & 945 \\
\hline 180 & 975 \\
\hline 210 & 1003 \\
\hline 240 & 930 \\
\hline 270 & +2 \\
\hline 300 & +2 \\
\hline 330 & +2 \\
\hline 360 & 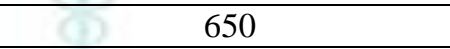 \\
\hline 390 & 547 \\
\hline 420 & 450 \\
\hline 450 & 343 \\
\hline 480 & +2 \\
\hline 510 & 215 \\
\hline 540 & 151 \\
\hline 570 & 120 \\
\hline 600 & 80 \\
\hline 630 & 50 \\
\hline 660 & 42 \\
\hline 690 & 37 \\
\hline 720 & 27 \\
\hline
\end{tabular}

Graph 1: Showing the Temperature pattern of Gaja puta of Mandura

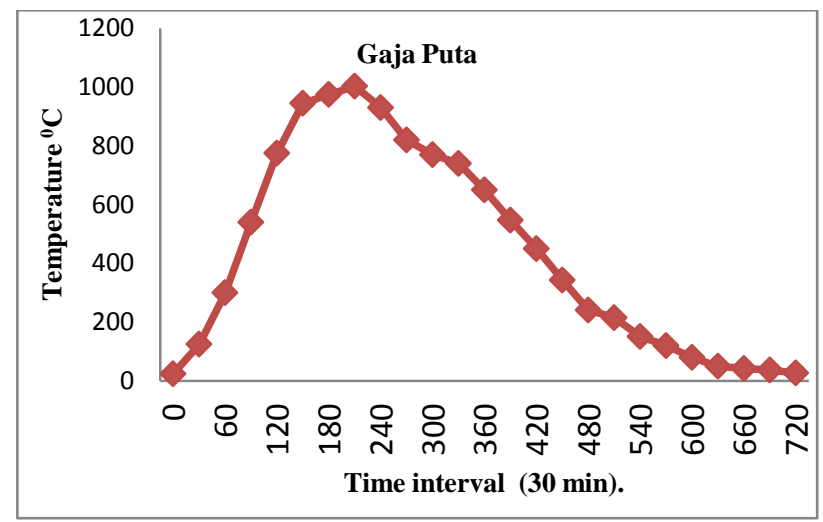


Table 5: Showing the Bhasma pareeksha of Mandura at different stages of Marana.

\begin{tabular}{|c|c|c|c|c|}
\hline Puta & Colour & Rekapuranata & Varitaratva & Slakshnata \\
\hline 1 & Black grey & - & - & - \\
\hline 2 & Dark grey & - & - & - \\
\hline 3 & Greyish brown & - & - & + \\
\hline 4 & Dark brown & - & - & ++ \\
\hline 5 & Dark brown & - & - & ++ \\
\hline 6 & Brownish red & + & - & +++ \\
\hline 7 & Red & ++ & + & +++ \\
\hline
\end{tabular}

Table 6: Showing the result of Churna Nirmana

\begin{tabular}{|c|c|c|c|}
\hline Name & Initial Weight & Final Weight & Loss in Weight \\
\hline Balamula churna & $200 \mathrm{~g}$ & $190 \mathrm{~g}$ & $10 \mathrm{~g}$ \\
\hline Satavarimula churna & $200 \mathrm{~g}$ & $185 \mathrm{~g}$ & $15 \mathrm{~g}$ \\
\hline Erandamula churna & $200 \mathrm{~g}$ & $195 \mathrm{~g}$ & $5 g$ \\
\hline Yava churna & $200 \mathrm{~g}$ & $180 \mathrm{~g}$ & $20 \mathrm{~g}$ \\
\hline Pippali churna & $200 \mathrm{~g}$ & $182 \mathrm{~g}$ & $18 \mathrm{~g}$ \\
\hline Jiraka churna & $200 \mathrm{~g}$ & $175 \mathrm{~g}$ & $25 \mathrm{~g}$ \\
\hline Twak churna & $100 \mathrm{~g}$ & $90 \mathrm{~g}$ & $10 \mathrm{~g}$ \\
\hline Patra churna & $100 \mathrm{~g}$ & $92 \mathrm{~g}$ & $8 \mathrm{~g}$ \\
\hline Ela churna & $100 \mathrm{~g}$ & $96 \mathrm{~g}$ & $4 g$ \\
\hline Nagakesara churna & $100 \mathrm{~g}$ & 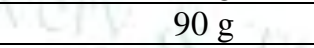 & $10 \mathrm{~g}$ \\
\hline
\end{tabular}

Table 7: Showing the result of Paka of all churnas along with Guda and Mandura Bhasma:

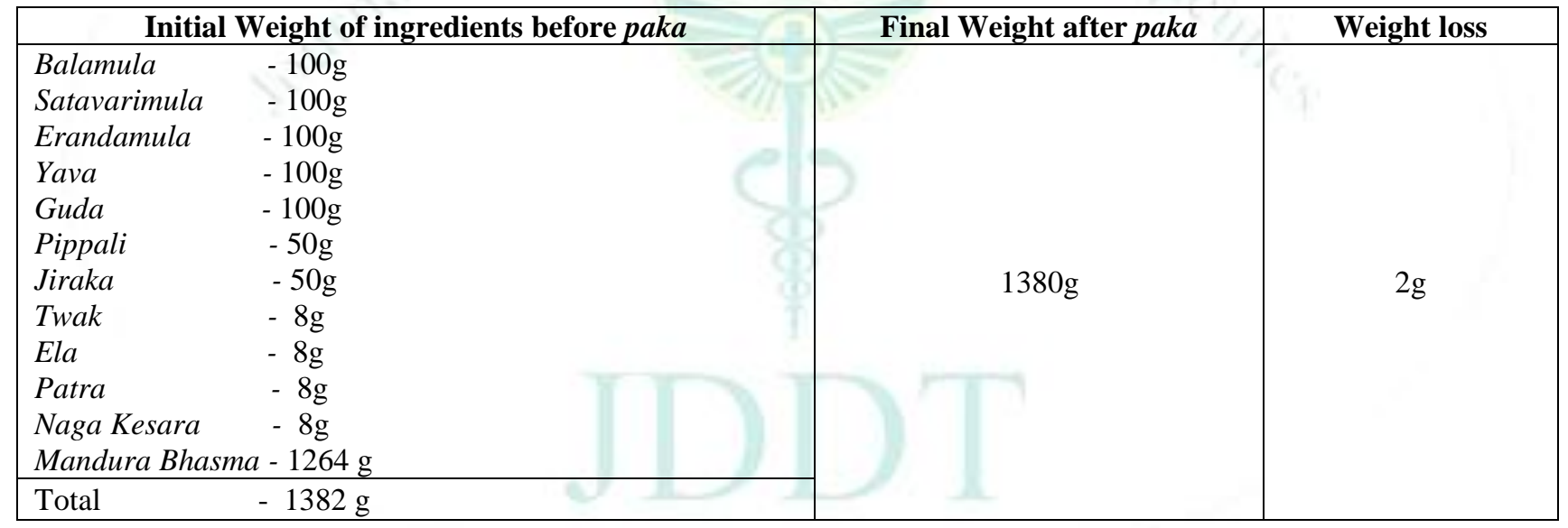

Table 8: Showing the result of preparation of capsules of Baladi Manduram

\begin{tabular}{|c|c|}
\hline Weight of homogenous mixture & Number of capsules prepared \\
\hline $1380 \mathrm{~g}$ & 2670 \\
\hline
\end{tabular}

\section{DISCUSSION}

The principle procedures involved in the present study are Nirvapa, Bhavana, Marana of Mandura, churna nirmana and preparation of Baladi Manduram.

Mandura Shodhana: Shodhana of Mandura was done to remove the visible and invisible impurities, to reduce the toxicity and to enhance the therapeutic properties. There are various methods mentioned for Shodhana of Mandura in Rasa Shastra texts. These procedures can be categorized as Nirvapa, Pachana, Abhiseka ${ }^{3}$ etc.

But in the present study, Nirvapa with Gomutra Triphala Kashaya has been selected for Shodhana procedure according to Rasa ratna samucchaya ${ }^{4}$. Nirvapa is the process of heating the material to red hot and quenching it into a liquid substance ${ }^{5}$. It makes the material more brittle by increasing the grain size. Gomutra Triphala Kashaya has been selected because Gomutra is having Tikshna, Laghu guna, Ushna virya and Lekhana properties ${ }^{6}$. Because of these properties it helps in breaking up of particles of Mandura and eliminates the undesired substances from the material. Secondly, the acidic impurities like chlorides, sulphides and nitrates present in Mandura might get neutralised by the alkaline Gomutra and get washed away. Due to hardness of Mandura (6 to 6.5) repeated heating and quenching (Nirvapa) in specific media disrupts the compression-tension equilibrium in the internal structure of Mandura.

In this Nirvapa method, during the process of heating weakening of electrostatic forces and crystal lattice of 
Mandura takes place. Because of the high temperature, more collision between the particles occurs (Collision theory $)^{7}$. Due to this weakening of bonds takes place which causes structural weakness that may develop into crack (Griffith theory) ${ }^{8}$. Immediate quenching in liquid media after heating causes disruption in compression tension equilibrium. This leads to increased brittleness and reduction in hardness of the material. As results of this, some part is converted to coarse powder and some in fine powder. After each quenching, powder was found as sediment in media.

Mandura Marana: Procedure of Marana is selected according to the reference mentioned in Rasamritam? According to the textual reference 7 putas have been mentioned for Mandura Marana. Mandura Marana includes four steps- Bhavana, Chakrika nirmana, Sharava samputikarana and Puta paka.

- Step I-Bhavana- Levigation: In the present study Mandura was subjected to Bhavana with Kumari Swarasa. Acharya Charaka has described Bhavana as one of the samskaras ${ }^{10}$. It is described that Bhavana with swarasa of specific dravya enhances the bala (potency) of aushadhi dravya. Bhavana helps in breaking down of the material by rubbing action between two surfaces i.e. surface phenomena, it is also called as attrition. When the stress in the form of attrition is applied, the particle surfaces chip and produce small particles. The particle size also gets reduced by this procedure. Moreover Kumari Swarasa used for Bhavana also acts as a binding agent, helps for disintegration of particles of the drug and adds some organic qualities and trace elements to the inorganic drug.

- Step II - Chakrika nirmana-Pellet formation: In this phase Bhavita dravya was converted in to small Chakrikas of uniform size and shape. This helps to achieve homogenous heat pattern to whole of the mass with increased surface area.

- Step III - Sharava samputikarana- placing the pellets in Sharava samputa: Earthen Sharava samputa are used for incineration because of their inert nature, easy availability and uniform distribution of heat to the substance.

- Step IV - Puta paka: In this phase, the Sharava samputa was subjected for puta paka. According to classics, Gaja puta is generally advised for Mandura Marana. Puta is the heating system which indicates the quantum of heat required by Rasadi dravyas for their conversion into suitable form (Bhasma) ${ }^{11}$. In puta system of heating there is gradual rise and fall of temperature which helps in making the material more agnisthayi (heat stable). It cannot regain its form back after complete procedure. The maximum temperature attained during the puta was $1003^{\circ} \mathrm{C}$. After that gradual fall in temperature was noted over a period of eight and half hours before reaching room temperature. The material turned to soft powder without any lustre after complete process, which indicates that the temperature was sufficient for the formation of the desired compound.

- There was a gradual change in the colour of the Mandura during putapaka. This indicates that the process of Marana and media have got direct influence and are responsible for change in "Varna, Nishchandratva and Shlakshanatva" of the Bhasma. It is evident from the analytical tests that increase in the percentage of iron oxide is contributing factor for the change in colour and loss of lustre.

- Bhasma pareeksha: Rekhapurnata was obtained at the end of $6^{\text {th }}$ puta. This indicates the Sukshmata of the Bhasma. After $7^{\text {th }}$ puta Varitaratwa was positive indicating the lightness of Bhasma. Mandura bhasma has achieved Gata rasatva property after $7^{\text {th }}$ puta.

- Preparation of capsules of Baladi Manduram: Baladi Manduram was prepared in the capsule form due to the presence of Volatile principles in Chaturjataka, which may get evaporated when exposed to environment.

\section{CONCLUSIONS}

Pharmaceutical standardization of medicines is an essential requirement to establish the safety and efficacy, as well as to ensure the quality and the yield of final product. Shodhana by Nirvapa in Gomutra Triphala Kashaya procedure helps in increasing the brittleness and reducing the hardness of the Mandura. Bhavana procedure plays a vital role in reducing the particle size and exposing maximum surface area of Mandura in Marana. Marana makes Mandura more adaptable, absorbable and assimilable in the body without producing any toxic effects. Hence all these procedures can be considered ideal in the standardization of the preparation of Baladi Manduram.

\section{CONFLICT OF INTEREST}

No conflict of interest.

\section{REFERENCES}

1. Acharya Sri Gulraj Sharma Mishra and Vaidya Santhosh Kumar Sharma, Rasa Kamadhenuh compiled by Sri Chudamani Mishra, Fourth Chikitsapada, Chapter 11, Verse no.41-44, Varanasi: Choukhambha Orientalia, 2014; p-214

2. Vaidya Pandit Hariprapanna Sharma, Rasa Yoga Sagara, Volume II, Pakaradi Rasa, Verse no. 1594-1597, Varanasi: Choukhambha Krishnadas Academy, 2010, p-107.

3. Prof.K.R.Srikantha Murthy, Sarangadhara Samhitha, Madhyama Khanda Chapter 11, Ver.100, Varanasi: Choukhambha Orientalia, 2010; 156.

4. Dr. Indradev Tripati, Sri Vagbhata virachitha Rasa Ratna Samucchaya, Chapter 5, Verse no.151, Varanasi: Choukhambha Sanskrit Samsthan, 2013; p-68.

5. Pandit Kasinath Shastry, Sri Sadananda sharma Virachitha Rasa Tarangini, Taranga 2 Verse no. 40, Varanasi: Motilal Banarasidas, 2014; p-19.

6. Padmashri - Prof. K.C. Chunekar, BhavaprakashNighantu (Indian materiamedica) by Shri Bhavamisra, Mutra Varga, Verse no. - 1-6; Varanasi: Choukambha Bharat Academy, 2015; p-761.

7. Collision Theory. n.d. In Wikipedia. Retrieved August 8, 2017, from https://en.wikipedia.org/wiki/Collision_theory

8. Fracture Mechanics. n.d. In Wikipedia. Retrieved August 8, 2017, from https://en.wikipedia.org/wiki/Fracture_mechanics

9. Dr. Damodar Joshi, Rasamritam of Vaidya Jadavji Trikamji Acharya, Chapter 3, Verse no. 49, Varanasi: Choukhambha Sanskrit Samsthan, 2007; p-95.

10. R.K. Sharma, Bhagvan dash, Agnivesa's Charaka Samhitha, Vol II Vimana sthana, Chapter 1 Verse no.22-II, Varanasi: Choukhambha Sanskrit Series Office, 2009; 124.

11. Dr. Indradev Tripati, Sri Vagbhata virachitha Rasa Ratna Samucchaya, Chapter 10, Verse no.47-50, Varanasi: Choukhambha Sanskrit Samsthan, 2013; p-114. 